\title{
Japanese Women Repatriated from the Colonies: Racial Conflicts and Agonies: A Studies on Nagareru Hoshi wa Ikiteiru (The Floating Stars Are Alive) by Fujiwara Tei
}

\author{
Wafa' Hanim Askho', Susy Ong ${ }^{2}$, Renny Nurhasana ${ }^{3}$ \\ \{ ${ }^{1}$ wafahanim.a@gmail.com, ${ }^{2}$ susy.ong66@gmail.com, ${ }^{3}$ rennynurhasana@ui.ac.id $\}$ \\ ${ }^{1,2,3}$ School of Strategic and Global Studies, Universitas Indonesia, Indonesia
}

\begin{abstract}
This studies focuses on the racial conflicts and agonies confronted by Japanese women during their long and uncertain journey home from Japan's former colonies, following Japan's military defeat in WW II, as depicted in Nagareru Hoshi wa Ikiteiru (The Floating Stars Are Alive) by Fujiwara Tei. This novel, a best-seller upon publication, is a semi-autobiography of the author. Japan's defeat to the Allied Powers in 1945 also resulted in the loss of her colonies (Taiwan, Korea peninsula and the puppet state 'Manchuria'), and Japanese nationals residing in those lands were forced to repatriate. The biggest numbers were from 'Manchuria', where Japanese civilians had been 'transmigrated' on masse. After Japan's defeat, the privileges they enjoyed before dismissed, and they became the target of racial assault by angry locals. More tragic were the women, since they were separated from their husbands, had to take care of their children during the journey, and frequently threatened by Korean males, social gap between Japanese, and individual experience with Soviet troops (Japan's former enemy). This personal story indeed is the testimony of one important part of Japanese modern history hitherto untold (unknown) to the public.
\end{abstract}

Keywords: decolonization, repatriation, racial tension, gender bias

\section{INTRODUCTION}

Japan's ambition to build an 'Empire' in Asia began with Japan's expedition to Taiwan in 1874 to expand its territory with a mission of colonialization and also military expeditions (Myers, 1984: 65). This expedition consequence by Taiwan's surrender as a colony after Japan's victory in the Sino-Japan war (1894-1895) in the part of Korean and Northern China (Manchuria). The greater Japanese influence in Asia the more hackled Russia, which until 1904 had resolved the territorial problems diplomatically with Japanese acceptance of the Chishima Islands (Kurils) instead of claiming Karafuto (Sakhalin) as Japan's. This tension led to the Russo-Japan war in 1904-1905 which was the second war located in Korea and Manchuria, and Japan got the South Karafuto as a victory. Treaty of Portsmounth (1905) also gave rights to the Liaodong Peninsula in Manchuria to Japan and territory protection of the Korean Peninsula in the same year which was later annexed in 1910, followed by establishing the South Manchurian Railway Company in Dalian (1906). [1] 
During World War I, 1914 Japan declared war on Germany (1914) and took over Shantung in the China and Western Pacific, which gave Japan some economic rights. A total of 72,000 Japanese troops were deployed in the Siberian Intervention (between 1918 and 1922) due to a mandate from the state. In the late of 1922, many Japanese soldiers still settled in Siberia and next to northern Manchuria, and also in Sakhalin (part of Soviet until 1925). Six years later (1931) a Manchurian Incident marked the founding of the Manchukuo puppet state the following year. This establishment was followed by the sending of 270.00 Japanese as permanent residents to farm in Manchukuo and parts of Mongolia. Expansion in the Asian region continued, by fighting the British in Burma (1941) and also urging the Dutch Government in Indonesia (1943) (Watt, 2002: 15-20). The number of Japanese was increasing year by year until losing the war, the Japanese spread in Asia, Siberia, and in the Asia Pacific reaches 6.5 million, with around 3.5 million of them were military troops, and the rest were civilians, including women and children. Specifically, around 2.6 million people were still in the China when the war ended, and 1.1 million people were scattered in Manchuria, some 600,000 war troops were in the islands of Kurile and Dalian (area of Port Arthur in southern Manchuria) and more than 500,000 people are in Formosa (Taiwan) and 900,000 people were in Korea. The rest of that number was spread to other parts of Southeast Asia (Dower, 1999: 49).

Imperialism which had been built for decades had collapsed with the announcement of Japan's agreement represented by Emperor Hirohito with the Postdam Declaration which also marked the end of World War II on August 15 (1945). Prior to this recognition, the US dropped atomic bombs on Hiroshima (August 6) and Nagasaki (August 9) and surrendered unconditionally on August 14. Japan's surrender to the official Allies was carried out with the signing of the Japanese government on September 2, 1945 aboard the USS Missouri in Tokyo Bay (Dower, 1999: 37-40). After that, the US, which in this case became an Allied force, took over the government in Japan as the result of Postdam Declaration and immediately carried out the first mission of demilitarization and democratization. [2] Especially in terms of demilitarization, the US was trying to mobilize troops outside of Japan, namely by providing ships for Japanese repatriation. This repatriation was initially only for soldiers or military members related to the demilitarization program, but for humanitarian reasons the US decided to repatriate Japanese civilians outside Japan. (Watt, 2002: 24).

This repatriation program was not only intended to repatriate Japanese people outside of Japan, but to repatriate non-Japanese in Japan, which were citizens of China, Taiwan, Korea, Okinawa, as well as German and Italian immigrants. There was a registration process to determine how many foreigners in Japan, which marks the treatment of the Aliens Registration Act. This process ran relatively fast and in November 1950 managed to repatriate nearly 1.3 million people. This step serves to promote nationalism in postwar Japan by returning Japan to 'purity' or homogeneity, where only Japanese people inhabit Japan which mentioned by Nanbara Shigeru (President and Political Specialist at Tokyo Imperial University) at the emperor's birthday 1946. Namely that the Imperial Japanese system, which is a symbol of Japanese national integration, must be constantly nurtured, because the integrity of The emperor and nation are more important than the sovereignty and conflict of the monarchic system, therefore now is the time to return to pure Japan from any other races, the history of Japanese personality will die if we do not obey the system (Yi Jin, 2014). [3]

On October 18 (1945), the Central Government established the Ministry of Welfare which was responsible for the return of Japanese people who were still outside of Japan and opened the Repatriation Relief Bureau on November 24 (1945). But due to the chaos of the situation outside Japan, RRB was finally established outside of Japan in March 1946. In September 
1946, over a year since the defeat of Japan, the government stated that more than 2.2 million Japanese had not returned yet, and the location and identity of about 540,000 people were unknown (Dower, 1999: 50). The establishment of the bureau did not necessarily facilitate the process of repatriation, because many civilians were repatriated without adequate assistance or protection from the Japanese government which prioritized military members and employees working in government and large corporations in Manchuria. As a result, during the repatriation process, they experienced bad things like contracting epidemic diseases, hunger and malnutrition, dying of illness or being killed, survive to afford money and food. In addition, the bad relations between the Japanese civilians and the local citizens especially Korean. Their representative of Japanese military and government that colonized Manchuria, caused bad treatment and intimidation from the locals. Even so, close to 1950, at least 6.24 million people (95\% of Japanese citizens who were eligible for repatriation) had returned to Japan, and by 1958 more than 6.29 million had been officially repatriated (Park, 2014).

Those kinds of obstacles experienced by civilians were not much highlighted in the study of Japanese history during World War II, but the other side of historical reality can be seen through literary work that tells the experience of repatriation of civilians. One of them is a semi-autobiography novel written by Fujiwara Tei entitled Nagareru Hoshi wa Ikiteiru (The Floating Stars Are Alive). This novel tells the author's experience during her journey back to Japan from Manchuria with her three children. By the Japan surrender, her family left Shinkyo (where he lived while in Manchuria) to Fengtien, and separated from her husband who had to go to Pyongyang, drawing ahead to Sengawa, Pyongyang, and end up in Busan before sailed to Hakata Port, Fukuoka. Her dangerous journey took about a year between August 1945 to September 1946 became a best seller in the Republic of Korea in the fall of 1949 to 1950. This book was translated by Cheong Kwanghyeon in Korean titled Naega Neomun 38 Seon (The 38th Parallel that I Crossed) in November 1949, sold up to 45,000 copies in seven months and helps Korean to raise awareness of their liberation (Kim, 2010). The narration about the struggles of Japanese women and their children received a lot of attention after a collective trauma experienced during the occupation of Japan suggests the need for analysis.

\section{METHOD}

This research uses qualitative method, descriptive analysis with socio-historical approach to examine Fujiwara's literature work. It is interested to know how the historical experiences of an author and her social group (e.g., a family, army, nation, or any other group of persons who are united together under some conditions) have affected the presentation of the material. This approach also analyze the relationship between a literary text and the social history of its author and her community. In this case, there is a close interrelationship between an author's social experiences and the text depicted on Fujiwara's work which is tell about the other side of World War II especially took place in Korea and Manchuria. Thus, in terms of themes, largely because of the socio-historical context, the writings show certain common features such as how the author overcome her struggles between Japanese fellow society or local citizen both Korean and Manchurian, also concern of author consciousness about her identity as Japanese based on a certain social and background of history that occurred at that time.

\section{DISCUSSION AND RESULT}

This novel tells the story of Fujiwara Tei's journey (abbreviated as FT) as the narrator, a wife of Hiroto Fujiwara, a Meteorologist who worked at the Meteorological Observation at 
Kwantung's military forces, as well as the mother of three Masahiro (6 years), Masahiko (3 years), and Saiko (1 month). FT moved to Manchuria from Suwa, Nagano in April 1943 because he followed her husband who was transferred by the Japanese government. A few days before the news of Japan was defeated, they began to pack and started the journey from Shinkyo Station along with other Meteorological Observation groups. But in September, before the departure of Shinkyo station, there was a command for men aged 18-40 year-old with healthy physical condition to immediately gather and depart to Pyongyang and Siberia.

Besides the absence of husband, her repatriation was not protected or guaranteed by Japanese government because she was not a member of the military but a civilian, so made them more vulnerable. Since that day, FT and the group must face difficulties during repatriation, such as financial difficulties demanded her to sell properties, soap, cloth dolls; and work as servants in Korean-owned taverns, health issues, bad weather, and other struggles through long and difficult terrain without the assistance of husbands or adult male members. Another obstacle was the different treatment between Japanese and intimidation from local residents, especially during their stay in Korea. But there is a special interaction between FT and Soviet soldiers who helped a lot during repatriation.

\subsection{The Hardship of Homecomings}

Difficulties faced by repatriates include starvation, infectious diseases, extreme weather and others could cause death. The same thing happened to FT group who suffered to reach their 'home'. Although in December 1945 there was food aid of rice twice a day for those who worked, many children died from starvation or digestive ailments due to lack of nutritious food intake. In addition, there was also a suspension of rice assistance in the early winter of 1946 which made FT cook porridge with grass (P. 133-134). Those who died, among others, were a 6-year-old child named Tomio Higashida who died of starvation, (p. 90), Ken, a child from Honda who unknowingly died due to indigestion (p. 109), and children from Sakiyama who died from acute malnutrition (p. 177). The death haunted other mothers who had children, including FT and her children who suffered diarrhea, malnutrition, diphtheria and fever alternately.

Furthermore, infectious diseases such as Yanji Fever or typhus killed approximately $80 \%$ of Japanese people were infected. (p.106). There are rumors that this disease was spread by prisoners who released from Pyongyang and returned to Manchuria through Yanji. Although many prisoners died during the journey, those who survived spread infectious diseases as long as they were quarantined (p.95). The news of the death rate was increasing, whether this infectious disease or because it failed to survive the journey (p. 172). Another challenge was the extreme temperatures during winter, especially when FT reaches the hill where the temperature can kill those who are negligent and overslept (p. 212), and also the repatriation path was not easy. The path chosen by FT and others was called the South Korean 38th Parallel Line, which requires them to climb a hill, cross a river, and pass through a steep rock road on foot, or just assisted by a cow to transport goods (p. 225).

Until September 1946, 540,000 of the 2 million Japanese who were still outside of Japan's territory had unknown fate because of heavy passage. The data noted, in the Manchurian region only, approximately 179,000 civilians and 66,000 members of the military died due to cold weather, lack of foodstuffs, and lack of healthcare as experienced by FT group. Again, summer and spring had been as terrible season as winter, because repatriates from central China had to face a smallpox outbreak in April, an outbreak of typhus in May, and cholera in 
June. The cholera outbreak reached South Korea and North Indochina in May, and Manchuria in August (Dower, 1999: 51).

Another strife that must be faced was the absence of her husband who could help to take care of their children during a long journey. Although many friends helped, FT must be mentally and physically strong to bring his children home safely. She continued to do her best to survive by selling her clothes, making soap (p.147) and cloth dolls and selling them (p. 169), giving her expensive watch to pay Masahiro's treatment when seriously ill (p. 174). No matter how hard it was, FT motivated to keep fighting. Even if she eventually dies, she wants to be as close as possible to her 'home' (p. 193). [4]

\subsection{The Depth Ravine Between Japanese}

Regarding the repatriation program held by the US in terms of demilitarization, the government's priority was to repatriate the military members and their families, even though by the end of September 1945 a repatriation system had been officially formed. Military members were top priority, followed by Shinto monks and geisha, while homeless and poor civilians became the last group to be repatriated officially (Watt, 2002: 25). Hence, the repatriated civilians before had to take care of themselves, even when they had helped, did not make their journey even easier. The priority given by the government makes some people treated unpleasantly, even by fellow Japanese. Similarly, FT, as woman who has three children was caused criticized.

When FT had been waiting for a few days at Pyongyang Station, a Japanese man shouted at her reading the letter from her uncle and touched. The man blamed FT, because of woman like her who did not immediately throw the letter away and became melancholy Japan lost (p. 196) [5]. Parallel to this happened when she was boarding to Busan by train, she was also criticized as a mother who did not have moral in public transportation because her weeping child disturbed other passengers as well as stingy smell of Masahiro who suffered diarrhea (p. 263). Meanwhile, she wanted to borrow magazine provided by the train, blasphemy also came from a father who refused to lend it considering mother should take care of children first instead of reading books (p.279).

Even though women's status gradually changing by centuries, their position remains as the second society. During the war there were many feminist movements, indeed, both fighting for education, labour justice, and the contribution rights in politic, but the military government made the qualification of ideal women and propagated them. The ideal women were widely promoted, especially in Manchuria, women must be strong so they could give birth healthy boys who can participate in the battlefield. This standard that requires them to educate their children perfectly even though they often struggle the financial burden at the same time because their husbands were recruited as warriors. So, when there are women who are weak and easily give up or choose to do other things instead taking care of children, they will be criticized because they do not meet the qualifications of Japanese women (Allen, 1958).

Arriving at the Hakata Port, FT felt very happy when receiving a repatriation identification card marked as her new life at home. On the other hands, realized that her return to Japan as 'Japanese repatriates and woman' became a new category in Japan. She was confused by Masahiro who saw a woman wearing a nice kimono dress saying "Mother, look at Japanese women walking". FT did not answer, he thought that women in Japan as defeated country were the same as her, looked pity and dirty. When compared to the woman, she was seen as a different person (p. 299). Then when FT arrived at Suwa from Hakata by train, she was greeted by students who welcomed the repatriates with loudspeakers, expressing their 
gratitude for surviving from struggles. The students mentioned them as 'hikiage no minasama (引揚げの皆様)' which means the 'repatriates' (p. 306). While resting in Suwa, FT found a written placard 'hikiage kyukeisho (引揚者休媳所)' or 'repatriate resting place', before meeting a grandmother on a bus from Hakata to Suwa who had pity on her thin children and gave them food (p. 310).

Those seem trivial but simply made FT feel alienated in their own country, feel like there was a separation between those who return from the colony country and those who living inland, and the terminology of separation in society, namely hikiagesha (引揚 者) and naichi (内地) arised. Hikiagesha (引 揚 者) means people who leave a foreign country back in their homeland (Matsuura, 1994: 278). Lori Watt defined specifically as those who were sent back to Japan after August 15, 1945, who maintained their livelihoods overseas continuously for more than six months, who had no choice but to return to Japan because of the conditions created aftermath, ordered by authorized state, as well as loss of property to support life or loss of livelihood. While the naichi ( 内地 ) literally means (1) original Japanese , ( 2 ) domestically, (3) inland (Matsuura, 1994: 686) , other meanings are those who lived in Japan until August 15, 1945 (Hammond, 2015). Although hikiagesha living in Japanese colonies were Japanese citizens, the environment had different culture that forms different attitudes and mindsets compared to Japanese citizens living inland. The distance is deliberately formed between naichi and hikiagesha because of having different experiences, namely hikiagesha who have to endure the defeat of Japan in the colonies by being treated badly and a long journey during the repatriation process. While naichi had to deal with the trauma of atomic bombs.

\subsection{The Revenge of Local Citizen}

Colonialization is generally hierarchical society, especially in race and gender, even in Korea and Manchuria during the Japanese occupation. Japanese citizens, members of the military, government, and factory employees had a higher position than the local citizen despite being a minority in terms of numbers. So the relationship between Japan and the local citizen, especially in Korea, did not always work well. The colonial government restricted a lot of Korean space (Myers, 1984: 492). Women also remain as second class after men. (Allen, 1958). In conjunction with the end of war, this hierarchical system should not apply, which also realized by the statement of FT when choosing leader of the repatriation group, while the candidate was wife of former leader, that when the war ended, status and social were no longer valid. [6] This also applies to local citizen, which means having equal positions to Japanese citizen because they had been unofficially liberated from colonial regulations. Nevertheless, the fall of the Japanese empire was used by local residents to show that Japanese position was underneath.

The status and social class that caused the racial conflict were seen when FT interacted with both Korean and Manchurian citizens who felt intimidated and ill-treated during Japan imperialism. Even though the members of military and government were more responsible, Japanese civilian who mostly had economic concern only representing Japan as invaders affected bad relationship between Japanese and local citizen. After Japan defeated, Japanese civilian mistreatment as an act of revenge. The treatment was not always physical abuse, but tended to racial conflict which increasingly highlighted after the war.

For instance, Koreans would be angry if they were called as Chosenjin (朝鮮 人) or 'Chosen'. Chosen was name given by Japan after the annexation of Korea as a colony in 1910 
(Myers, 1984: 17), so it has intimidating and humiliating meaning for Korean. Even during colonialization period, chosenjin or shortened as sennin also had derogatory meaning and indicated that Korea still under Japanese control. Therefore, when Japan defeated, Korea was 'independent' from colinization, they no longer wanted to be called chosenjin. To minimize conflict, FT preferred kochira no hito (こちらの 人) or local people (p. 60).

Another example is that some Korean men often approached FT's resting places on one of the hills before reaching Pyongyang and claimed that they were emissaries of their husbands who were taken to Pyongyang. This incident disrupted FT's mind, because Koreans who had good intentions would not interact this close, and only look at each other, or if there was a small child, they will give food and leave without saying anything. Again, because indeed the relationship was not good during the colonialization, and the tension increased after the war was over. This racial conflict made FT group choose not to interact or react to anything if there was intimidation from Korean citizens (p. 63). The interference of Korean men was seen as a form of self-actualization, showing that the hierarchical position during colonialization had been flipped. By intimidating and harassing FT groups, showed that Koreans were in a higher position than FT with a complex position as 'woman' of 'defeated country', caused their conditions more vulnerable.

FT, whose position was very vulnerable, lead to a preventive and passive measure their safety, so she kept the distance when dealing with Korean, even though they are female. One day, FT had to sell her homemade soap around her resting place in Korea to survive. A colleague did not recommend her to sell soap in a stone-fenced house owned by local citizen because it would certainly be rejected. But due to urgent circumstances, she finally came to the house and was greeted by a woman dressed in Korean kimono. They did not welcome, did not refuse, forbidding FT from saying anything and blaming Japanese politics for the war that afflicted Koreans (especially), and even Japanese civilians became victims, so they deserved to be pitied. Instead, when FT would offer her homemade soap, the woman said that she would help but not directly deliver the items so that FT would not exile by others because of receiving help from Korean, by 'throw' Korean rice, miso and pickles away to FT. The word used by this woman was not ageru (上 げる) which means 'giving', but chose suteru (捨 て る) which means 'to throw away' with the intention of humiliating Japanese, and told FT to immediately 'levy' (お拾いなさい - ohiroinasai) food that has been discarded/not required (p.157). [7]

The woman's attitude was ambiguous, she blamed the Japanese government because during the colonization of her country, on the other hand it remains pleasing to assist FT as a Japanese civilian even though the language indicates that FT was beneath. After the war ended, Japan left an impression that made Korea feel love and hate even now, or Janus-faced on Bruce Cumings's term. Just few of them were aware that Japan was building modernization in Korea by developing a super-fast economy, a successful military, and also education with compulsory and development programs in school. Thus, they welcomed freedom with a deep rejection of Japanese colonialism, but also could not easily eliminate how much Japan contributed to the development of Korean modernization (Myers, 1984: 482).

\subsection{Victory Kindness}

The Soviet, which became the enemy of Japan far before World War II began, capitalized on the moment of Japan's defeat by bringing more soldiers both in Manchuria (Craig, 1967: 250). FT also interacted with the Soviet forces which after Japan lost the war came to 
Manchuria and Korea. FT which previously had bad impression as described by the Japanese government so far, initially felt insecure if it was close or met with one of them. However, after meeting directly, FT realized that they were not that bad (p. 169). Instead, they helped her by giving patchwork as a material for making dolls for sale. She was doubt when approaching the Soviet office, but she received a warm welcome (p. 165). When FT met with members of the Soviet when peddling her dolls, she was afraid but unexpectedly they gave three Korean banknotes. Even many of them who were being a good friend with children and often visit FT groups to entertain (p. 169).

The bad relationship between Japan and the Soviet or Russia was tapering before the Russo-Japan war in 1903. The struggle over territories that occurred including Karafuto or Sakhalin, the Cold War and anti-communist propaganda echoed after World War II ended also showed bad relations between these two countries (Dower, 1986: 309). But reality unfold different situation, intertwined micro-or grassroots relations between FT and some of them were very nice therefore could change the impression and view of FT towards the Soviets.

\section{CONCLUSION}

Long before the war began, gender issues have been serious matter (even endless I suppose), especially during the war were still as important issue. The end of the war did not necessarily solve the problem faced by women, which in this case was represented by FT on her work, making the struggles she had to overcome became heavier and caused more vulnerable. Women become second class in society because they are considered weak, even though on the one hand they are demanded to be strong. Nonetheless, the way FT survives during the repatriation period shows that women are able to survive and grow into strong individuals even in bitter situations.

In the socio-historical context, the writing of FT, which contains individual memory represents the collective memory of the people who experience the same story, is contributing historical evidence hence can be seen objectively as the other side of history which not widely revealed and commonly discussed in historical studies. Especially relating to Japan in WWII, because the written history is a version of the government that has political interests to lead public opinion as their necessity. Regarding repatriation case focuses on technical matters such as how to mobilize many Japanese citizens from their colonies or how many ships have been used. While the story regarding how repatriates survive the difficulties of the repatriation field, the interactions occur during that time and the psychological trauma aftermath are not much written in the historical text.

\section{ACKNOWLEDGEMENT}

This research based on grant scheme of PITTA (Publikasi International Terindeks untuk Tugas Akhir) 2018 or also known as Indexed International Publications for Final Projects toward Universitas Indonesia students.

\section{REFERENCES}

[1]. Allen, Pongsun Choi. 1958. Changes in The Status of Japanese Women. The Ohio

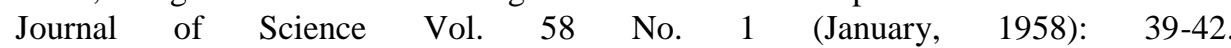
https://kb.osu.edu/dspace/bitstream/.../V58N01_039 
[2]. Anonim. 1984. World War II in the Pacific National Historic Landmark Theme Study. https://www.nps.gov/nhl/learn/themes/WWIIinPacific.pdf

[3]. Hammond, Kilby. 2015. The Question of japanese-ness: Repatriation and Guilt in Postwar Japan. Asia Pacific Perspectives. http://www.usfca.edu/center-asiapacific/perspectives/

[4]. Kim, Michael. 2010. The Lost Memories of Empire and the Korean Return from Manchuria, 1945-1950: Conceptualizing Manchuria in Modern Korean History. Seoul Journal of Korean Studies 23, no. 2 (December 2010): 195-223.

[5]. Yi Jin, Park. 2014. The Postwar Experince of Repatriates: The Crack in Postwar Japan's reconstruction. Sungkyun Journal of East Asian Studies Vol.14 No.1 Academy of East AsianStudies. 43-63.

[6]. Dower. John W. 1986. War Without Mercy. New York: Pantheon Books.

[7]. 1999. Embracing Defeat in the Wake of World War II. New York: Norton and Company.

[8]. Fujiwara, Tei. 1976. Nagareru Hoshi wa Ikiteiru. Japan: Chuokoron-shinsha, INC.

[9]. Myers, Ramon Hawley, Mark R. Peattie and Jingzhi Zhen. 1984. The Japanese Colonial Empire, 1895-1945. Princeton: Princeton University Press.

[10]. Matsuura, Kenji. 1994. Kamus Bahasa Jepang-Indonesia. Kyoto: Kyoto Sangyo University Press.

[11]. Watt, Lori. 2002. When Empire Comes Home: Repatriation in Postwar Japan, 19451958. Disertasi: Columbia University.

[12]. Treaty of Portsmouth, (Sept. 5 [Aug. 23, Old Style], 1905), peace settlement signed at Kittery, Maine, U.S., ending the Russo-Japanese War of 1904-05. According to the terms of the treaty, which was mediated by U.S. President Theodore Roosevelt, the defeated Russians recognized Japan as the dominant power in Korea and turned over their leases of Port Arthur and the Liaodong Peninsula, as well as the southern half of Sakhalin Island, to Japan. Both powers agreed to restore Manchuria to China. (https://www.britannica.com/event/Treaty-of-Portsmouth)

[13]. The Postdam Declaration point (7) Until such a new order is established and until there is convincing proof that Japan's war-making power is destroyed, points in Japanese territory to be designated by Allies shall be occupied to secure the achievement of the basic objectives we are here setting forth. (http://www1.udel.edu/Historyold/figal/hist371/assets/pdfs/potsdam.pdf)

[14]. The Emperor system, which is the best expression of Japan's national authority and the symbol of Japan's national integration, will be and must be maintained eternally. This has been affirmed based on the integration of the nation's long history, and it is the immutable essence of the Japanese ethnic community based on the "oneness of Emperor and nation," which transcends the conflicts of monarchism and popular sovereignty. Now, as we have returned to a pure Japan without "different races from other areas," Japan's historical individuality and spiritual independence will perish if we betray the system.

[15]. どうせ死ぬにしても故郷へ一歩でも近づいて死にたい。

[16]. 「おい,そこの女の人,なぜ早く手紙を破らないのか,きみのような女がいるから 日本は負けたんだぞ,なにをぐずぐずしているんだ,早く捨てないか，それでも 日本人の女か」

[17]. 終戦とともに古い階級も身分もないはずであったが、やっぱりこうした場合で も大体前の経歴によって標準がきめられるものらしい. (p. 36) 
[18]. 「日本人,ほんとうに気の毒だと思っています.だが,今 あなたにものを上げると ，私 は村八分にされ ます.今まで私たちが苦労していたのは日本の政治が悪か ったからだ と, 日本人をみんな恨んでいます.でも,あなた方にはなんの罪もあ りません.今，私がものを捨てますから，あなたは,それを急いで お拾いなさい $」$ 